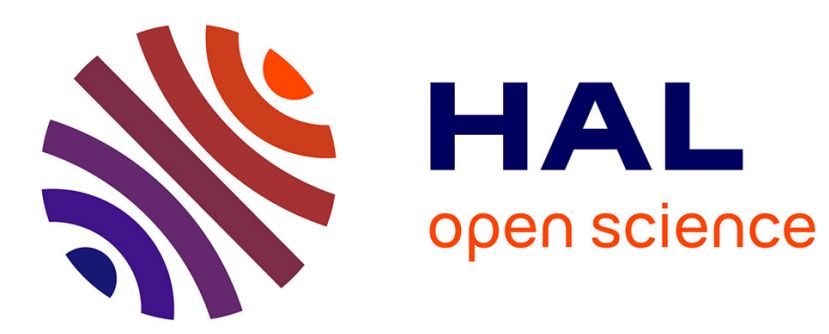

\title{
Variability in protein composition of pea seed studied by FPLC and multidimensional analysis
}

\author{
A. Baniel, D. Bertrand, Andre Lelion
}

\section{To cite this version:}

A. Baniel, D. Bertrand, Andre Lelion. Variability in protein composition of pea seed studied by FPLC and multidimensional analysis. Crop Science, 1998, 38 (6), pp.1568-1575. hal-02687899

\section{HAL Id: hal-02687899 \\ https://hal.inrae.fr/hal-02687899}

Submitted on 1 Jun 2020

HAL is a multi-disciplinary open access archive for the deposit and dissemination of scientific research documents, whether they are published or not. The documents may come from teaching and research institutions in France or abroad, or from public or private research centers.
L'archive ouverte pluridisciplinaire HAL, est destinée au dépôt et à la diffusion de documents scientifiques de niveau recherche, publiés ou non, émanant des établissements d'enseignement et de recherche français ou étrangers, des laboratoires publics ou privés. 


\title{
Variability in Protein Composition of Pea Seed Studied by FPLC and Multidimensional Analysis
}

\author{
A. Baniel, D. Bertrand, A. Lelion, and J. Guéguen*
}

\begin{abstract}
The nutritional and the functional quality of pea (Pisum sativum L.) seed depends primarily on their protein content and composition. For breeding as well as for industrial uses, efficient methods for analyzing protein composition are of great importance. In the present work, a procedure combining fast protein liquid chromatography and statistical analysis was developed for routine determination of protein composition in pea seed. Chromatographic conditions optimized the resolution and repeatability of peak areas and peak retention times sufficiently for statistical analysis. The analytical procedure was a practical compromise between the time of chromatographic separation and the repeatability of the fractionation. The method utilizes the variability among pea cultivars and the repeatability of their chromatographic profiles and can characterize seed protein composition with sufficient precision to distinguish cultivars.
\end{abstract}

$\mathrm{P}$ EA IS A LONG ESTABLISHED and significant crop in Europe, but its production has been rather low for a long time. The increasing need of protein-rich raw materials for animal feed or intermediary products for human nutrition have led to a greater interest in these plants as a protein source. However, production of peas

A. Baniel, A. Lelion, and J. Guéguen, Unité de Biochimie et Technologie des Protéines, INRA, rue de la Géraudière - B.P. 71627 - 44316 NANTES Cedex 03, France; D. Bertrand, Unité de Technologie Appliquée à la Nutrition, INRA, rue de la Géraudière - B.P. 71627-44316 NANTES Cedex 03, France. Received 5 Dec. 1996. *Corresponding author (gueguen@nantes.inra.fr).

Published in Crop Sci. 38:1568-1575 (1998). for industrial uses is at present rather limited by the variability in their biochemical composition (Matthews and Arthur, 1985; Guéguen, 1991).

As with other crops, variability in pea seed composition results from both genotypic and phenotypic factors (Casey et al., 1982; Schroeder, 1982; Cousin, 1983; Guéguen and Barbot, 1988; Turner et al., 1990). Many authors (Casey et al., 1982; Higgins, 1984; Boulter et al., 1987) have shown that pea storage proteins are encoded by a multiplicity of genes, which induce this great polymorphism. Moreover, the heterogeneity of protein molecules is increased by post-translational modifications (Thomson and Schroeder, 1978; Matta and Gatehouse, 1982; Müntz, 1989), especially cleavage and glycosylation, leading to a large number of constitutive polypeptides. Similarly, the genes at the $r b$ and $r$ loci of the third and seventh chromosomes, which code for wrinkled and smooth characters of pea seed, have a pleiotropic effect on storage proteins (Kooistra, 1962; Turner et al., 1990; Perez et al., 1992). Turner et al. (1990) showed, using near-isogenic lines, that the transcription rates for genes corresponding to a particular cDNA clone for legumin were similar in $R R$ and $r r$ embryos. A difference in the mRNA levels was the result of an increased degradation of legumin mRNA in $r r$ relative to $R R$ embryos. Several authors have considered the phenotypic aspect (Randall et al., 1979; Chandler et al., 1983; Higgins, 1984; Rerie et al., 1991) and showed that external nutritional supplies can induce alterations in the rates of vicilin and legumin synthesis. 
Finally, morphological factors, such as the position of the pea within the pod or the location of the pod on the plant, can determine seed protein content and composition (Cousin et al., 1985; Matthews and Arthur, 1985; Bertholdsson, 1990; Cousin, 1992).

In most of the previous studies, the variability of the protein composition was evaluated on the basis of seed protein content, vicilin/legumin, and albumin/globulin ratios. These methods produced rather crude data. First, they provided only poor resolution and consequently did not discriminate among some protein families. Second, they did not take into account protein polymorphism. In the present study, a rapid chromatographic analysis of the pea seed proteins, coupled with multidimensional analysis, was developed to overcome these drawbacks. Using multidimensional analysis of the chromatogram profiles, we expected that samples could be distinguished not only on the basis of quantitative variations of each protein group, but also on qualitative differences due to protein polymorphism. The development of such a routine analytical method for protein composition analysis would be very useful in breeding programs striving to improve the protein quality of the seed.

\section{MATERIALS AND METHODS}

To develop the analytical method, six pea cultivars were evaluated: two supplied by INRA (Institut National de la Recherche Agronomique, France)—Amac and Alaska Sweet, two by Euretec (France)-Madria and Maxi, and two by the John Innes Institute, Norwich (UK) - Midfreezer and Keerau. Anti-proteases (benzamidine (B-6506), phenylmethylsulfonyl fluoride (PMSF, P-7626), leupeptine (L-2023), and ethylenediaminetetraacetate (EDTA, E-1644) as chelating agent were obtained from SIGMA (St Quentin, France).

\section{Extract Preparation}

Seeds $(15 \mathrm{~g})$ were ground by a two-step procedure, first in a refrigerated IKA mill (A 10S, Janke and Kunkel, Staufen, Germany) $\left(4^{\circ} \mathrm{C}\right)$ for $30 \mathrm{~s}$ and then in a refrigerated Dangoumeau mill (Ref. 49336, Prolabo, Paris) $\left(4^{\circ} \mathrm{C}\right.$ ) for $5 \mathrm{~min}$ to provide a flour having an average particle size smaller than $160 \mu \mathrm{m}$. The protein fraction was extracted according to a method described previously (Guéguen and Barbot, 1988) by stirring $1 \mathrm{~g}$ of flour for $1 \mathrm{~h}$ in $15 \mathrm{~mL}$ of $50 \mathrm{mM}$ Tris/HCl buffer, $\mathrm{pH}$ 8.5, 0.3 $M$ potassium sulphate, with addition of anti-proteases ( $1 M$ benzamidine, $1 M$ PMSF, $1 M$ leupeptine), $1 \mathrm{~m} M$ EDTA, and $0.7 \mathrm{~m} M$ 2-mercaptoethanol.

\section{Anion Exchange Fast Protein Liquid Chromatography (FPLC)}

Fast protein liquid chromatography was carried out with a Kontron 400 automatic system (400, Kontron, St Quentin). Chromatographic data were stored on an IBM-compatible microcomputer by Kontron software (D450, Kontron, St Quentin). Anion exchange chromatography was performed on a Pharmacia MonoQ HR 5/5 (Pharmacia Biotech AB, Uppsala) analytical column equilibrated with $50 \mathrm{mM}$ Tris/HCl buffer, $\mathrm{pH}$ 8.5. Before injection, samples were filtered through a $0.2-\mu \mathrm{m}$ Millipore membrane (Millipore Corp., Milford, MA), then the proteins were eluted (flow rate $1 \mathrm{~mL} / \mathrm{min}$ ) by a $\mathrm{NaCl}$ gradient $(0-0.5 M)$. After each run, the column was cleaned with $5 \mathrm{~mL}$ of $2 \mathrm{M} \mathrm{NaCl}$ and then equilibrated with the $50 \mathrm{mM}$ Tris/ $\mathrm{HCl}$ buffer. Cleaning was improved by injecting successive $500-\mu \mathrm{L}$ aliquots of $0.75 M$ acetic acid, $500 \mu \mathrm{L}$ of $2 M$ $\mathrm{NaOH}$, and $2 \mathrm{~mL}$ of $2 \mathrm{M} \mathrm{NaCl}$ after every 50 samples. Under these conditions, the experimental problems due to variations of flow rates were avoided, even when 24-h runs were performed for routine analysis.

\section{Quantitative Determination of the Protein}

The sample relating to each peak was collected and the protein quantified by the Bradford method (Bradford, 1976). The Kjeldahl method could not be employed on chromatographic fractions because the protein concentration was too low. Since the binding of the dye employed in the Bradford technique is greatly influenced by the physico-chemical characteristics of the protein, preliminary assays were performed to select the proteins for standard curves. Bovine serum albumin was used to establish the standard curve for the whole albumin fractions, while purified legumin was used for the globulin fractions. The respective amounts of protein corresponding to each peak was then expressed as a percentage of the total protein loaded on the column. The protein extract concentration $(\mathrm{N} \times 5.6)$ was determined by the standardized Kjeldahl method (AOAC, 1990, 976.06). The value of 5.6 was considered as a more accurate coefficient factor than the convention value of 6.25 for the nitrogen to protein conversion in pea seed (Mossé, 1990).

\section{Polyacrylamide Gel Electrophoresis}

SDS-polyacrylamide gel electrophoresis (SDS-PAGE) was performed in a gradient $\left(100-200 \mathrm{~g} \mathrm{~L}^{-1}\right)$ as described by Laemmli (1970). Samples were reduced prior to electrophoresis by incubation at $100^{\circ} \mathrm{C}$ for $1 \mathrm{~min}$ with $0.7 M 2$-mercaptoethanol (SIGMA M7154).

\section{Indirect Enzyme-Linked Immunosorbant Assay (ELSA)}

Legumin, vicilin, trypsin inhibitor, and lectin were detected by indirect ELISA in the various chromatographic fractions. Ninety-six wells microtiter plates were coated overnight at $20^{\circ} \mathrm{C}$, with $100 \mu \mathrm{L}$ per well of the eluted fractions. Each fraction was preliminary diluted by $1 / 2,1 / 100$, and $1 / 1000$ with $0.05 M$ sodium carbonate buffer, $\mathrm{pH} 9.6$, to reach a suitable concentration (about $1 \mu \mathrm{g} / \mathrm{mL}$ ) for coating. Protein-coated plates were then washed and saturated with gelatin $(10 \mathrm{~g}$ $\mathrm{L}^{-1}$ ) and incubated with anti-legumin, anti-vicilin, anti-trypsin inhibitor, and anti-lectin rabbit sera. These sera, prepared in our laboratory by injecting the corresponding purified proteins to rabbits, are characterized by a very high specificity; no cross-reaction with other proteins were observed. After $1 \mathrm{~h}$ at $37^{\circ} \mathrm{C}$, the plates were washed and incubated with peroxidasecoupled goat anti-rabbit IgG (Engvall and Perlmann, 1971). Enzyme activity was quantified colorimetrically with $O$-phenylenediamine at O.D. $490 \mathrm{~nm}$ (Quillien et al., 1995).

\section{Amino Acid Composition}

Pea flours and freeze-dried protein extracts were hydrolyzed for $24 \mathrm{~h}$ at $110^{\circ} \mathrm{C}$ with $6 \mathrm{M} \mathrm{HCl}$ in evacuated and sealed tubes. The amount of sample subjected to hydrolysis (in $7.5 \mathrm{~mL} 6 \mathrm{M} \mathrm{HCl}$ ) corresponded to $10 \mathrm{mg}$ of protein. Sulfur amino acids were determined after performic acid oxidation (Moore, 1963) as cysteic acid and methionine sulphone. The amino acids were derivatised with the phenyl isothiocyanate (PITC) method described by Bidlingmeyer et al. (1987) and determined as phenylthiocarbamyl derivatives. The hydroly- 
zates were evaporated in a vacuum rotary evaporator and washed twice with distilled water to eliminate $\mathrm{HCl}$ traces. The residue was then solubilized in a 2:1:1 mixture of ethanol, water, and triethylamine (TEA) and then dried again. The resulting sample was dissolved in a 7:1:1:1 mixture of ethanolwater-TEA-PITC. The phenylthiocarbamyl derivatives obtained were analyzed by reverse phase HPLC on a Waters Pico-Tag column $(3.9 \mathrm{~mm}$ by $15 \mathrm{~cm}$ ) (Millipore Corp.) in a linear acetonitrile gradient $(0-600 \mathrm{~mL} / \mathrm{L})$ over $40 \mathrm{~min}$ (flow rate $1 \mathrm{~mL} / \mathrm{min}$ ).

\section{Statistical Analysis}

Principal components analysis (PCA) was used for reducing a set of correlated variables to a simpler set of orthogonal components. PCA is the well-known method, described in many statistical text books, by Jolliffe (1986). This method leads to synthetic variables which are a combination of the original ones according to:

$$
C_{k i}=\sum_{j=i}^{n} u_{i j} \times V_{k j}
$$

where $C_{k i}$ is the $i$ th synthetic variable of the $k$ th observation; $u_{i j}$ is the $j$ th component of the $i$ th unit eigenvector; $V_{k j}$ is the $j$ th variable of the $k$ th observation; and $n$ is the number of original variables. The synthetic variables are principal components. By means of the PCA algorithms, these components are orthogonal to each other.

PCA was performed on the whole set of chromatograms which were divided into 465 successive data points $(n)$, each point corresponding to $2.58 \mathrm{~s}$ and an elution volume of 4.3 $10^{-2} \mathrm{~mL}$. The interval between two points was optimized to generate the data file of minimum size which could lead to a chromatographic profile which fit exactly with the experimental profile without loosing information and resolution. The average absorbance of each segment defined by two successive points on the chromatogram was taken as the original variable. In the present case, $V_{k j}$ in Eq. [1] represented the $j$ th point, associated to $J$ th retention time, of the $k$ th chromatogram.

PCA is able to achieve the decomposition of experimental chromatogram into a weighted sum of a few theoretical profiles, the dimension of which being that of a chromatogram ( $n$ in Eq. [1]). These theoretical profiles are ranked, by PCA, in the order of their decreasing contribution for reconstructing a given chromatogram. They are obtained from the $u_{i j}$ values in Eq. [1]. They can be graphically represented by curves we have called theoretical chromatographic profiles by plotting $u_{i j}$ for a given value of $i$, as a function of $j$ (or equivalently as a function of retention time). A low value of index $i$ corresponds to a theoretical chromatographic profile contributing as a major component to the experimental chromatograms. In the present case, it was sufficient for discriminating the various chromatograms to examine only the first and second major theoretical profiles. These profiles could be interpreted in term of chromatography. The peak and local minima are representative of the variations of protein composition from one chromatogram to another. For a given experimental chromatogram $k$, the contribution of the Profile $i$ is quantified as the factorial coordinates $c_{k i}$ in Eq. [1]. Thus, the factorial coordinates are, in a way, equivalent to concentrations and the theoretical chromatographic profiles are analogous to chromatograms of pure products. But contrary to real chromatograms, the intensities can be either positive or negative. There is therefore a correspondence between a given profile $u_{i j}$ and the factorial coordinates $c_{k i}$. A high value of $c_{k i}$ means that the theoretical Profile $i$ is a major component of the corresponding chromatogram $k$. In the present work, as two theoretical profiles ( 1 and 2 ) were sufficient for discriminating the chromatograms, the corresponding factorial maps were

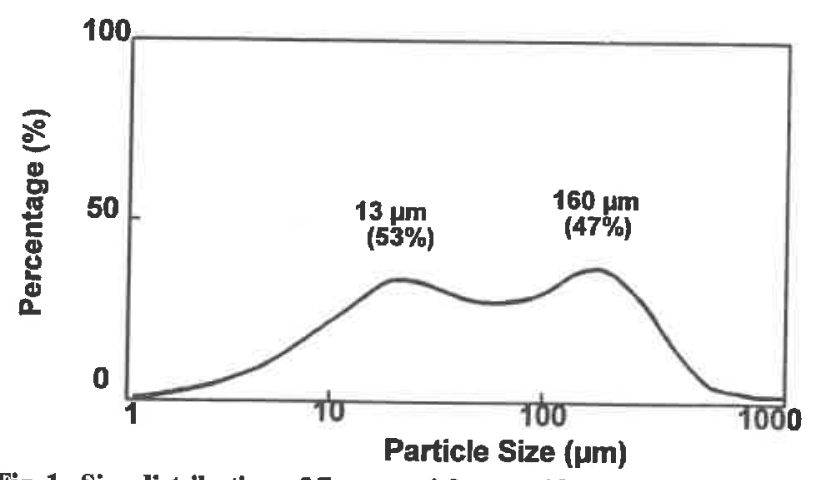

Fig. 1. Size distribution of flour particles provided by sequential millings of mature peas, in a helix mill and a ball mill.

obtained by plotting, for all the chromatograms, the values of $c_{k I}$ on $X$-axis and $c_{k 2}$ on $Y$-axis. Axes $X$ and $Y$ therefore corresponded to the first and second theoretical profiles, respectively.

By means of this technique, similar chromatograms give neighboring points on the factorial map, whereas two points far from each other in the plane represent very different chromatographic features. The procedure was applied to a collection of thirty chromatograms, corresponding to FPLC analyses performed in duplicate on five different protein extracts for each cultivar Amac, Alaska-Sweet, and Midfreezer.

\section{RESULTS AND DISCUSSION Extract Preparation}

The initial aim of this study was to define the analytical conditions needed to achieve repeatability between duplicate samples that was sufficient for statistical analysis. Each step of the analysis, i.e., grinding, extraction and FPLC chromatography, had to be standardized. Grinding was a critical step because it determined the extraction yield, which was dependent on particle size and integrity of the proteins in the flour. From preliminary assays, it was observed that an average particle size smaller than $200 \mu \mathrm{m}$ had little influence on the protein extraction yield. To achieve this particle distribution in the flour, we adopted a two-step grinding procedure which avoided the denaturation of proteins by heating. With a helix mill, the seeds were first ground into coarse particles which were then finely ground in a ball mill. The resulting flour was composed of two main populations of particles with average particle sizes of about 13 and $160 \mu \mathrm{m}$ (Fig. 1).

To verify the repeatability of the protein extraction on this finely ground flour, 10 protein extractions were performed on the same cultivar (Madria) and the protein concentrations evaluated by the Kjeldahl method. The coefficient of variation for total protein extract was $2.2 \%$, which was considered satisfactory for this routine analytical method. The percentage of extracted protein varied from 75 to $90 \%$ depending on the cultivar analyzed, however. This result revealed a relatively large variation in the insoluble protein fraction among cultivars, which has not been characterized in detail previously. The present results, therefore, only relate to the composition of the soluble protein fractions.

To examine the difference between total and soluble proteins, an amino acid analysis was performed for three cultivars, in duplicate and on both the flours and the 


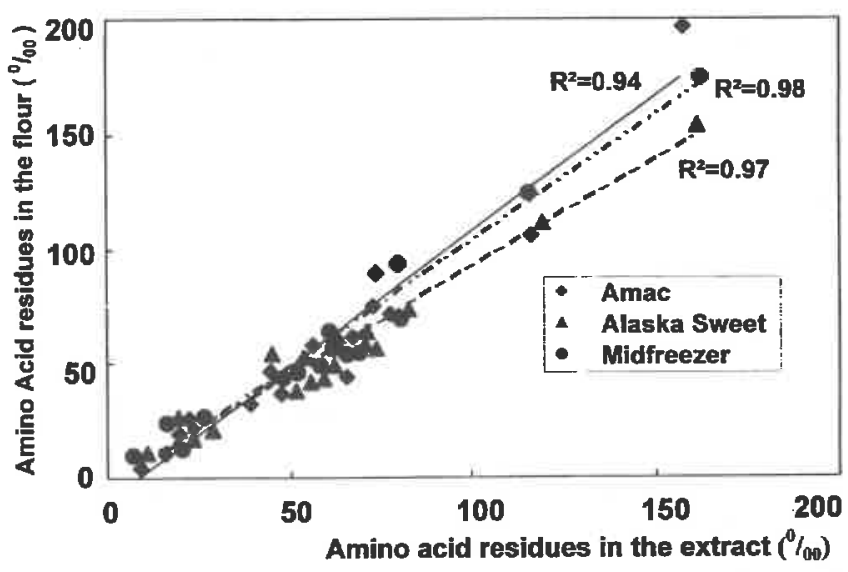

Fig. 2. Comparison of the amino acid concentration in the flour and the protein extract of three pea varieties. (Critical values for correlation coefficients: $R^{2}=0.48, P<0.05 ; R^{2}=0.61, P<0.01 ; R^{2}=$ $0.72, P<0.001)$

corresponding protein extracts. The comparison was performed by plotting the amino acid composition of the extract versus that of the flour. Figure 2 shows the slopes of the regression lines did not equal 1.0, indicating the protein extraction was not complete for the three cultivars studied. However, the determination coefficients $\left(R^{2}\right)$ were considered satisfactory, even for the lowest value of 0.94 obtained for the variety Amac; given the number of samples tested, the linear regression for Amac would be significant at $0.1 \%$ probability for a $R^{2}$ value at 0.72 . This analysis indicated a close correspondance between the protein composition of the flours and extracts, thus validating the conditions used for protein extraction.

\section{FPLC Chromatography}

The protein extracts processes by anion exchange FPLC eluted as six main peaks from the MonoQ column (Fig. 3). The relative percentage of protein recovered in each peak is presented in Table 1 . A very small proportion $(2 \%)$ of the total protein eluted in the void volume (Peak 1); gradient elution separated components into the next four peaks (Peaks 2-5). For Madria and Maxi, Peak 5 quantitatively represented the major protein fraction (Table 1).

The concentration of protein in Peak 1 was too low to be easily detected by Coomassie staining after SDS-
Table 1. Percentage protein recovered from anion exchange FPLC fractions ohtained for the cultivars Madria and Maxi. Experimental conditions and peak numbers as in Fig. 3.

\begin{tabular}{lcc}
\hline Cultivar & $\begin{array}{c}\text { Peak } \\
\text { number }\end{array}$ & $\begin{array}{c}\text { Relative percentage } \\
\text { of protein recovered }\end{array}$ \\
\hline \multirow{4}{*}{ Madria } & 1 & 1.7 \\
& 2 & 19.4 \\
& 3 & 10.7 \\
4 & 30.3 \\
5 & 39.4 \\
Maxi & 6 & 0 \\
& 1 & 2 \\
& 2 & 17.1 \\
& 3 & 27 \\
& 4 & 43.3 \\
\hline
\end{tabular}

PAGE (Fig. 4), even after five fold concentration of the fraction. By silver staining the electrophoregram, Peak 1 appeared to contain a mixture of proteins which were eluted mainly in the Peaks 2 through 5 (data not shown). The proteins in Peaks 2 ( $a$ and $b$ ) and 3 (a and b) corresponded to albumins $\mathrm{PA}_{2}$ (MW 26000) and $\mathbf{P A}_{1}$ (MW 11000), whereas convicilin (MW 71000 ), vicilin (main constitutive polypeptides MW $\sim 47000,33000$ ) and legumin ( $\alpha$ polypeptides $\mathrm{MW} \sim 45000, \beta$ polypeptides MW $\sim 25000$ ) were eluted in the Peaks 4 ( $a$ and b) and 5 (a and b). Peak 6 contained non-protein material as indicated by the protein analysis data (Table 1), the lack of bands in SDS-PAGE (Fig. 4) and the lack of absorbance at 275 to $280 \mathrm{~nm}$.

ELISA results were consistent with SDS-PAGE patterns; legumin eluted mainly in Peak 5 and vicilin and convicilin eluted in Peak 4 ( $a$ and b) (Fig. 5). The shoulders of these peaks (Fig. 3) correspond to various isoforms of these storage proteins. Some isoforms of vicilin were detected in trace amounts in Peak 1 . Lectins and trypsin inhibitors, which are quantitatively minor proteins, thought to be antinutritional factors, were detected primarily in Peaks 1 and 2 (a and b). A small quantity of lectins was also detected in Peaks 3 (a and b) and 4 ( $a$ and $b)$.

By means of this resolutive chromatographic method, the four pea varieties examined in this study could be distinguished easily by their FPLC elution profiles. As illustrated in Fig. 6, the chromatogram for each variety was unique in terms of the elution times or relative areas of the main peaks. For example, Peak 5 is very

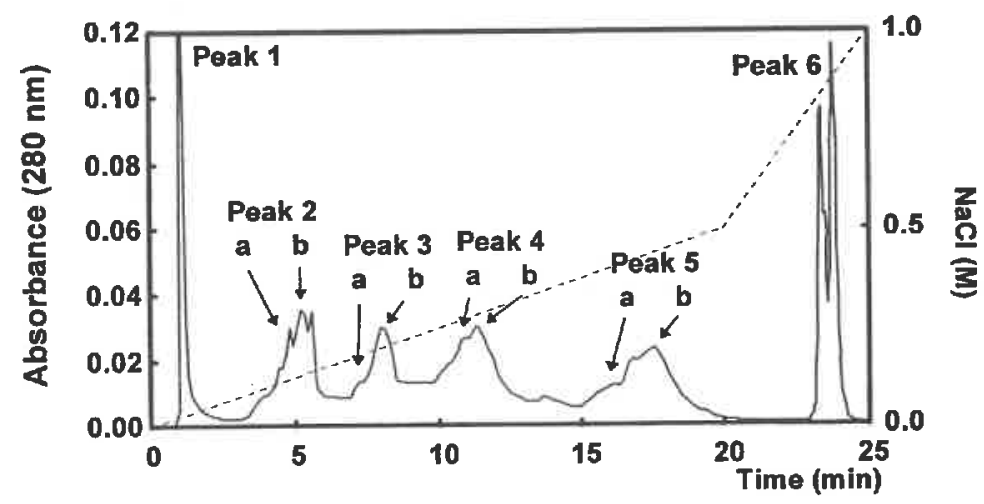

Fig. 3. Anion-exchange FPLC elution profile of pea proteins (Amac cultivar, column MonoQ HR 5/5, $50 \mathrm{mM}$ Tris-HCl buffer, pH 8.5 , o- $0.5 \mathrm{M}$ $\mathrm{NaCl}$ gradient, flow rate $1 \mu \mathrm{L} \mathrm{min}{ }^{-1}, 20 \mathrm{~mL}$ of protein extract loaded, $0.13 \mathrm{mg}$ protein). 


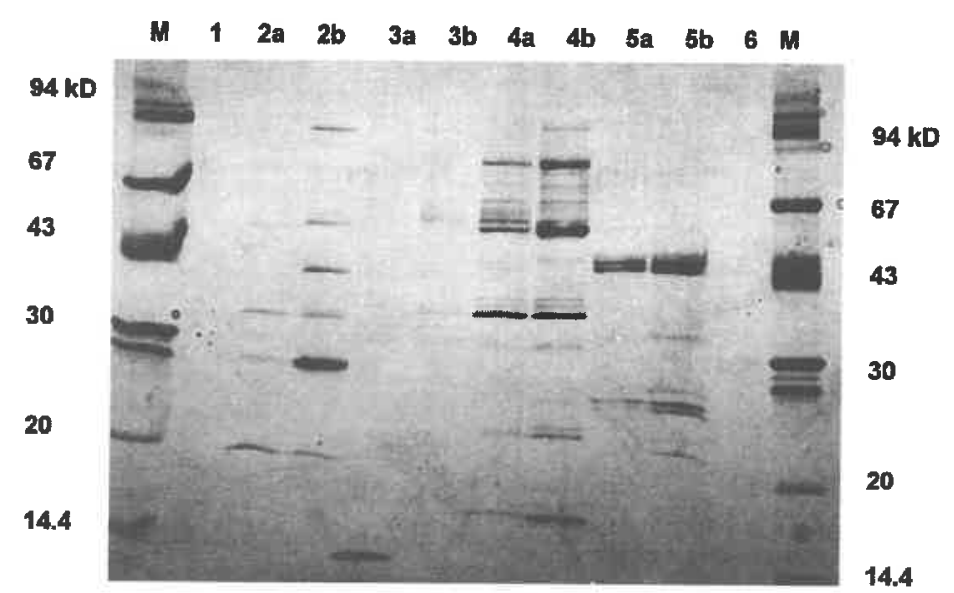

Fig. 4. SDS-polyacrylamide gel electrophoresis of protein fractions obtained by anion-exchange FPLC of pea seed protein extract (Amac cultivar). Around $10 \mu \mathrm{g}$ of protein solubilized in HCl buffer pH 6.8, $6.9 \mathrm{mM}$ SDS (25 $\mu \mathrm{L}$ ), and reduced by 2-mercaptoethanol loaded on the gel. Identification of lanes corresponds to peaks in Fig. 3. $M$ denotes molecular weight markers.

large for Keerau pea, but rather small for the three other varieties. In contrast, Peak 2 is large in Alaska Sweet and Midfreezer, and smaller in Keerau pea and Amac. The satisfactory discrimination of these pea varieties based on FPLC analysis and informed interpretation suggested that an automatic system for determinating protein seed composition could be developed to enable characterization and discrimination of a large number of cultivars. The primary source of error of such a method in most cases is the repeatability of the chromatographic procedure.

Baniel et al. (1992) highlighted the importance of storage conditions for the protein extracts to increasing the repeatability of the chromatographic fractionation Consequently, antiproteases were added to the extract buffer and the samples were kept at $4^{\circ} \mathrm{C}$ on the FPLC autosampler before analysis. To check the repeatability of the whole experimental procedure, seven extractions of the same flour from cultivar Amac were performed over a 2 -wk period, the extracts being randomly distributed on the FPLC autosampler and analyzed with other protein samples. The coefficients of variation for the mean peak area and the mean retention times for the five main protein peaks are very low, with a maximum coefficient of variation of $4.2 \%$ for the retention time and of $1.9 \%$ for the peak area (Table 2). These results are comparable to those obtained by Wingad et al. (1986) on RP-HPLC profiles of barley (Hordeum vul- gare L.) proteins and better than those of Buehler et al. (1989) on RP-HPLC profiles of soybean [Glycine $\max (\mathrm{L}$.$) Merr.] proteins.$

\section{Multidimensional Analysis of Chromatographic Data}

A study was performed with chromatograms of protein extracts from three pea varieties to estimate the efficiency of the PCA technique in discriminating among chromatograms. It was readily apparent that including Peak 1, which contained a mixture of very small amounts of non-adsorbed proteins, in the analysis produced mathematical artifacts unsuitable for statistical analysis. The distribution of the chromatograms in the factorial map was more closely related to the order of analysis than to the protein composition of the extracts. This result is characteristic of a time shift of the nonadsorbed protein peak. The probable explanation of this distribution is a slow evolution of the column with time. Very weak packing of the gel induces a uniform acceleration of the non-adsorbed proteins in the column which did not affect the elution of the adsorbed proteins with $\mathrm{NaCl}$. For this reason, non-adsorbed proteins in Peak 1 , which represented only $2 \%$ of the extracted proteins, were excluded from further statistical analysis of the chromatographic profiles.

A plot of eigenvalues of the centered and normalized

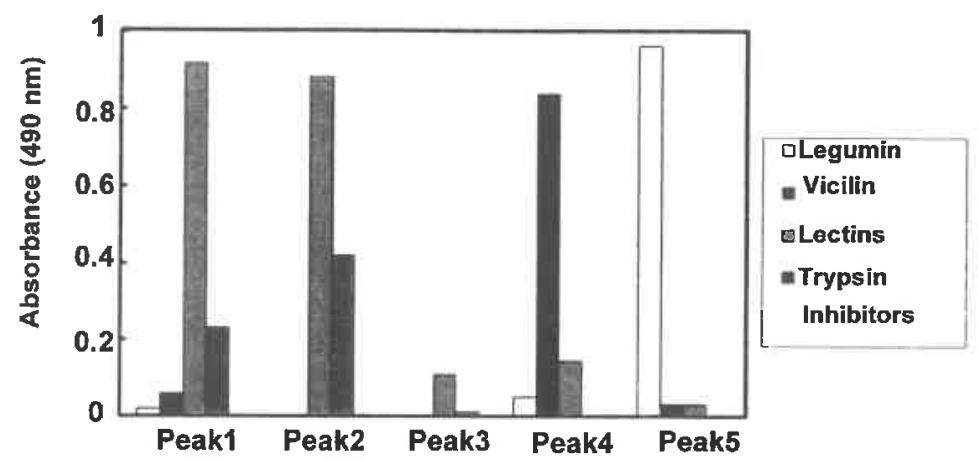

Fig. 5. Qualitative measurement of five seed proteins in pea variety Amac by indirect ELISA. 

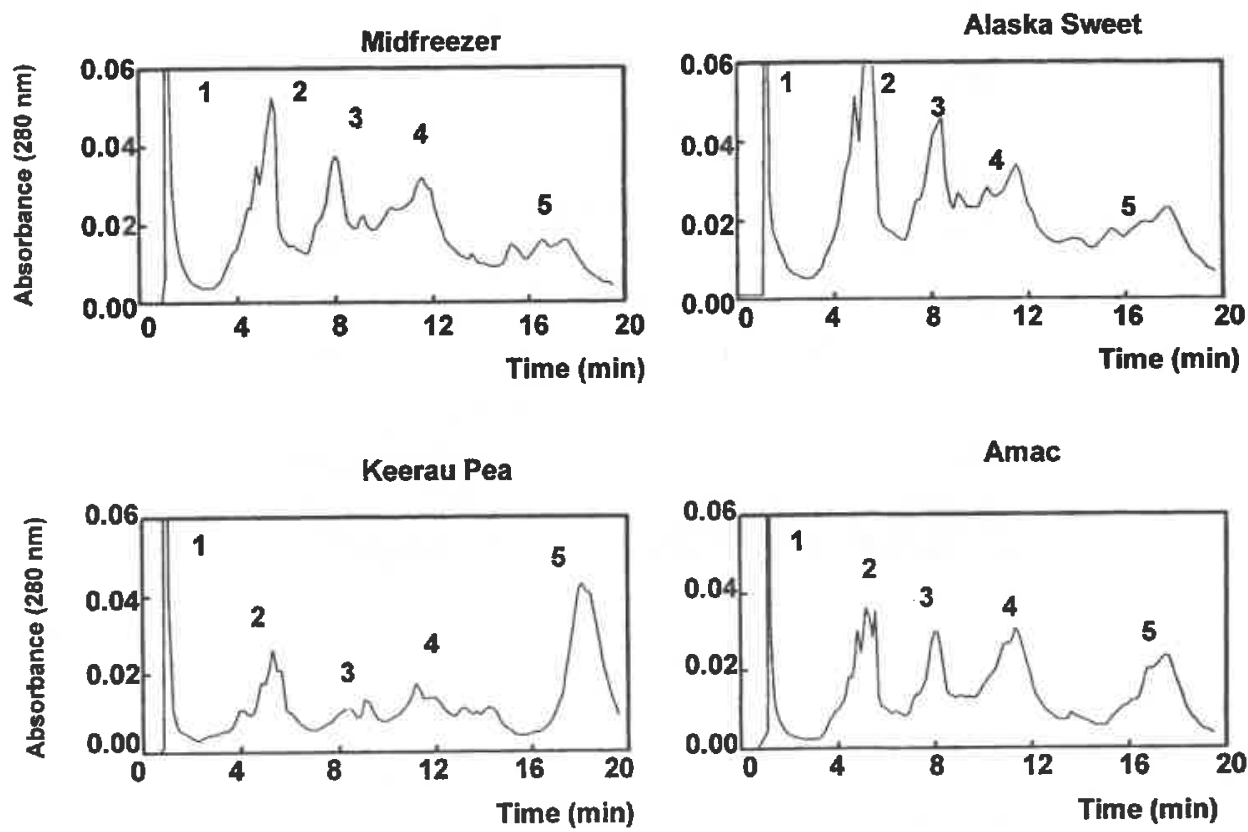

Fig. 6. Anion-exchange FPLC elution profiles of seed proteins from four pea cultivars. (column MonoQ $\mathrm{HR} 5 / 5,50 \mathrm{mM}$ Tris-HCl huffer, pH $8.5,0-0.5 \mathrm{M} \mathrm{NaCl}$ gradient, flow rate $1 \mathrm{~mL} \mathrm{~min}^{-1}, 20 \mu \mathrm{L}$ of protein extract loaded, $0.13 \mathrm{mg}$ protein).

PCA performed on the 30 chromatograms show that fewer than 10 principal components, assimilated in the present study as theoretical chromatographic profiles, were sufficient to describe $100 \%$ of the total informations (Fig. 7). The first and second principal components together represent $82.2 \%$ of the cumulative variance. Since these two components represent so great a proportion of the variation between the chromatograms, they were selected as axes of the factorial map used to distinguish the various chromatograms (Fig. 8).

The two axes corresponding to the first and second principal components, as such, represent theoretical chromatographic profiles (Fig. 9 a, b). The peaks, positive or negative, consequently, correspond to the protein fractions. Axis 1 is characterized by two negative peaks corresponding to elution times of about 5.5 and $8.8 \mathrm{~min}$, and two positive peaks at elution times of 10.8 and 17 $\mathrm{min}$. These values are typically those of the two albumins (Peaks 2 and 3, Fig. 3) and two globulins fractions (Peaks 4 and 5, Fig. 3). This result signifies that the samples are discriminated on Axis 1 by the contrast between these two opposing protein groups, albumins and globu-

Table 2. Repeatability of peak area and retention time for rapid anion-exchange chromatography of pea proteins (Amac cultivar). Mean peak area and mean retention time are the average values obtained from the elution profile corresponding to seven different protein extracts. The extractions were performed over 2 wks and the extracts randomly analysed with other samples to take into account some potential variations of the column efficiency.

\begin{tabular}{lcccc}
\hline $\begin{array}{l}\text { Peak } \\
\text { number }\end{array}$ & $\begin{array}{c}\text { Mean peak } \\
\text { area (Rel.) }\end{array}$ & $\begin{array}{c}\text { Coefficient of } \\
\text { variation (\%) }\end{array}$ & $\begin{array}{c}\text { Mean retention } \\
\text { time (min) }\end{array}$ & $\begin{array}{c}\text { Coefficient of } \\
\text { variation (\%) }\end{array}$ \\
\hline 1 & 14.7 & 2.8 & 1 & 1.9 \\
2 & 20.5 & 2.2 & 5.5 & 0.5 \\
3 & 17.3 & 4.2 & 8.1 & 0.7 \\
4 & 27.5 & 0.9 & 11.2 & 1.3 \\
5 & 20.0 & 1.9 & 17.4 & 1.4 \\
\hline
\end{tabular}

lins. This is in agreement with the distribution of the chromatograms on the factorial map (Fig. 8), clustered in three small areas corresponding to the genotypic origin of the protein extracts. The Midfreezer cultivar, which shows a rather high proportion of albumin (Peaks 2 and 3) compared with globulin (Peaks 4 and 5) (Fig. 6), is on the left side of the factorial map (Fig. 8). In contrast, Amac characterized by a higher proportion of globulins (Fig. 6) is on the right side of the map. The pattern of Axis 2 (Fig. 9b) also shows a contrast between albumins and globulins, as positive and negative peaks respectively. However, the relative importance of the first albumin peak, corresponding to Peak 2 of the chromatograms, is increased considerably compared to Axis 1. This means that cultivars rich in albumin and especially in $\mathrm{PA}_{2}$ should be well discriminated on Axis 2 . Alaska Sweet, the cultivar richest in this albumin fraction, is situated at the top of the factorial map and the two other cultivars, which contain less of this fraction, are situated at the bottom (Fig. 8). Thus, this statistical

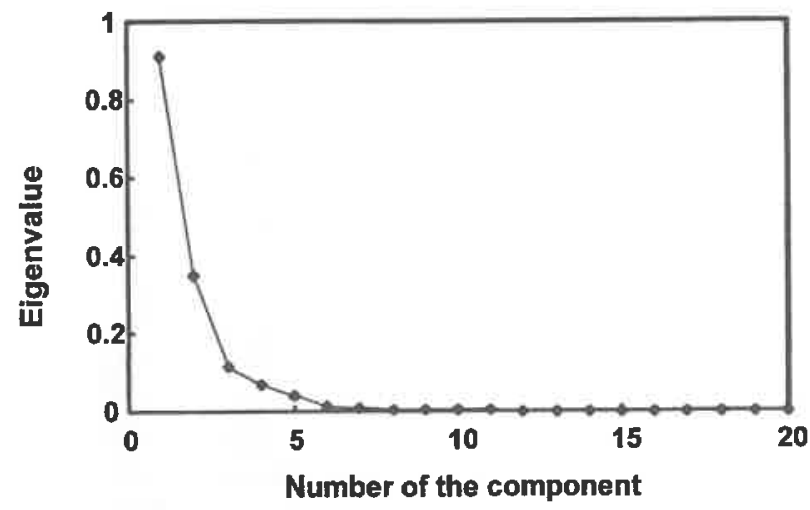

Fig. 7. Eigenvalues for the principle component analysis performed on 30 chromatograms of pea seed proteins separated by FPLC. 


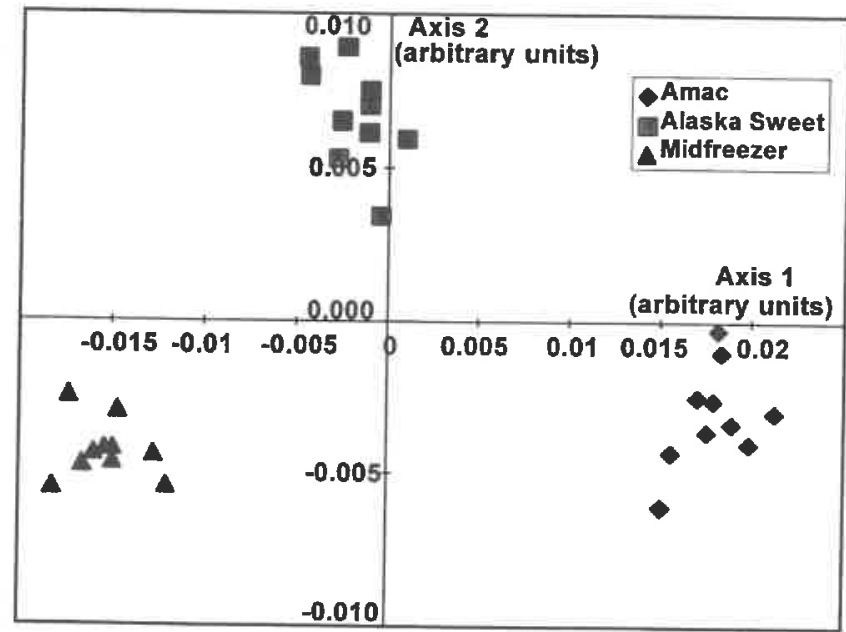

Fig. 8. PCA factorial map of chromatograms discriminating the three genotypes Amac, Alaska Sweet, Midfreezer. The two axes as first and second principal theoretical profiles have the dimension of chromatograms. Each point on the biplot consequently represents an experimental chromatogram. Chromatograms of seed proteins from the three pea cultivars are roughly discriminated on Axis 1 according to their relative content in albumins and globulins and on Axis 2 especially according to their $\mathbf{P A}_{2}$ content.

approach is an efficient tool for discriminating pea cultivars on the basis of their protein composition.

These results indicate that anion-exchange FPLC is a powerful method for evaluating the variability in protein composition of peas. Similar approaches developed for wheat (Triticum aestivum L.) (Batey, 1984; Scanlon et al., 1989; Larré et al., 1991; Courcoux et al., 1992), soybean cultivars (Buehler, 1989), are not suitable for peas because pea globulins would dissociate into subunits under RP-HPLC denaturating conditions generally used in these studies. FPLC with an aqueous eluting buffer on the other hand allows the separation of native globular proteins and constitutes an improvement not only for pea but also for oligomeric seed proteins of other legumes.

Characterization of protein composition under nondenaturating conditions also can be performed by ultracentrifugation, but this technique is time consuming and has less resolution. Electrophoretic techniques offer better resolution but only under denaturating conditions; moreover, their rather poor repeatability seriously limits data computation for both qualitative and quantitative measurements. Immunochemical techniques are powerful tools for the measurement of one or two protein groups, but are not well suited for studying the complex protein composition of whole seed.

Coupled with multidimensional analysis, the FPLC chromatographic method represents an original and efficient new approach, which could be employed for routine analysis of pea proteins. Rapid and highly sensitive, it may be useful for inter-cultivar discrimination. The high capacity for analysis with automated sample handling was tested successfully in our study by many continuous 24-h runs. Moreover, factorial analysis of chromatograms offers a means to reduce the amount of data required to distinguish the polymorphism of the storage
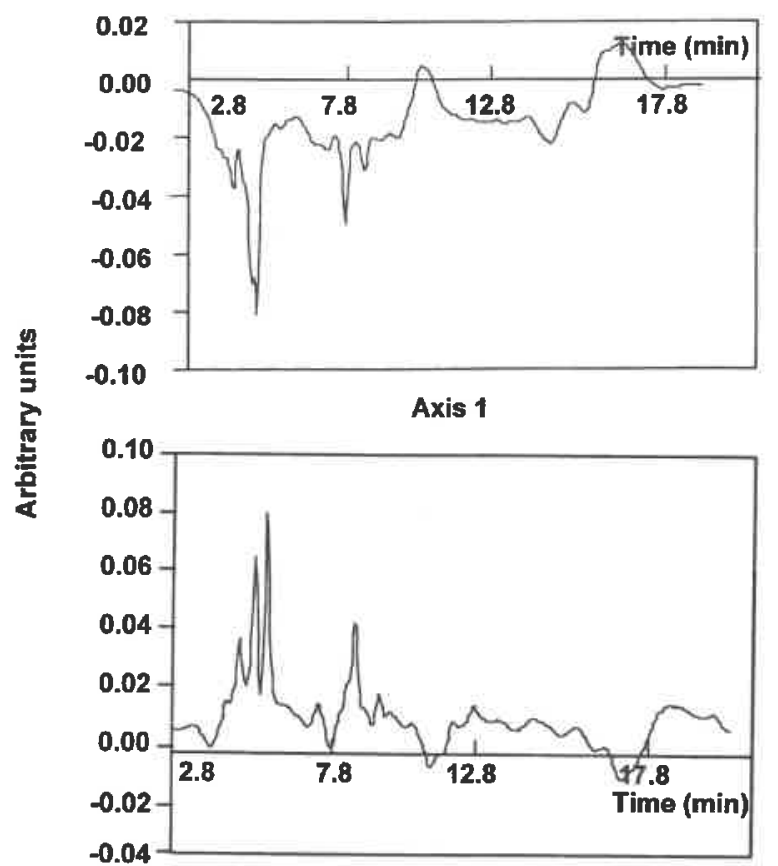

Axis 2

Fig. 9. Theoretical chromatographic profiles representing the first and second principal components chosen for discriminating the genotypes. They correspond respectively to Axis 1 and Axis 2 of the factorial map. To avoid Peak 1 interference, the chromatograms were truncated for the first $165 \mathrm{~s}$. Positive and negative peaks of these theoretical chromatograms are corresponding to the albumin and globulin peaks as identified on experimental chromatograms. Theoretical chromatographic Profiles 1 (Axis 1) is characterized by two strong negative albumin peaks and two weaker positive globulin peaks. Theoretical chromatographic Profiles 2 (Axis'2) mainly exhibits a very strong and composite albumin peak.

proteins, which is an important factor of the qualitative variability.

Our approach should make studies focusing on the influence of environmental and genetic factors on protein composition easier and more objective. It also becomes feasible to create a protein fingerprint of the pea species in a computerized collection of FPLC chromatograms.

\section{ACKNOWLEDGMENTS}

Thanks to L. Quillien and T. Gaborit (INRA-Nantes) for providing antibodies and their help in using the immunochemical techniques. Thanks are also due to UNIP (Union Interprofessionnelle des Plantes riches en protéines) for their financial support.

\section{REFERENCES}

AOAC. 1990. Official method of Analysis 976.06. Protein (crude) in animal feed. Semiautomated method. p. 72-74. In K. Helrich (ed.) Official method of analysis, 15 th Edition. Association of Official Analytical Chemists, Arlington, VA.

Batey, I.L. 1984. Wheat varietal identification by rapid ion-exchange chromatography of gliadins. J. Cereal Sci. 2:241-248.

Baniel, A., D. Bertrand, and J. Guéguen. 1992. Variability of protein composition in pea seeds: Studies by high-performance liquid chromatography. p. 409-410. In P. Plancquaert (ed.) Proc. of the First European Conference on Grain Legumes, Angers, France.1-3 June 1992. Assoc. Eur. Protéagineux, Paris. 
Bertholdsson, N.O. 1990. The influence of the pea plant ideotype on seed protein content and seed yield. J. Agron. Crop Sci. 164:54-67.

Bidlingmeyer, B.A., S.A. Cohen, T.L. Tarvin, and B. Frost. 1987. A new, rapid, high-sensitivity analysis of amino acids in food type samples. J. Assoc. Anal. Chem. 70:241-247.

Boulter, D., I.M. Evans, J.R. Ellis, A. Shirsat, J.A. Gatehouse, and R.R.D. Croy. 1987. Differential gene expression in the development of Pisum sativum L. Plant Physiol. Biochem. 25(3):283-289.

Bradford, M., 1976. A rapid and sensitive method for the quantitation of microgram quantities of protein utilizing the principle of protein dye binding. Anal. Biochem. 72:248-254.

Buehler, R.E., M.B. McDonald Jr., T.T. Van Toai, and S.K. St. Martin. 1989. Soybean cultivar identification using high-performance liquid chromatography of seed proteins. Crop. Sci. 29:32-37.

Casey, R., J.E. Sharman, D.J. Wright, J.R. Bacon, and P. Guldager. 1982. Quantitative variability in Pisum seed globulins: Its assessment and significance. Plant Foods Hum. Nutr. 31:333-346.

Chandler, P.M., T.J.V. Higgins, P.J. Randall, and D. Spencer. 1983. Regulation of legumin levels in developing pea seeds under conditions of sulfur deficiency. Rates of legumin synthesis and level of legumin mRNA. Plant Physiol. 71:47-54.

Courcoux, P., T. Sérot, C. Larré, and Y. Popineau. 1992. Characterization and identification of wheat cultivars by multi-dimensional analysis of reversed-phase high-performance liquid chromatograms. J. Chromatogr. 596:225-232.

Cousin, R. 1983. Breeding for yield and for protein content in pea. p. 146-164. In R. Thomson and R. Casey (ed.) Perspectives for peas and lupins as protein crops. Martinus Nijhoff, The Hague.

Cousin, R. 1992. Research on genetic factors for combining pea quality (Pisum sativum). p. 53-54. In P. Plancquaert (ed.) Proc.of the First European Conference on Grain Legumes, Angers, France.1-3 June 1992. Assoc. Eur. Protéagineux, Paris.

Cousin, R., A. Messager, and A. Vingere. 1985. Breeding for yield in combining peas. p. 115-129. In P.D. Hebblethwaite et al. (ed.) The pea crop. A basis for improvement. Butterworths, London.

Engvall, E., and P. Perlmann. 1971. Enzyme-linked immunosorbent assay. ELISA. Quantitative assay of immunoglobulin G. Immunochem. 8:871-874.

Guéguen, J., and J. Barbot. 1988. Quantitative and qualitative variability of pea (Pisum sativum L.) protein composition. J. Sci. Food Agric. 42:209-224.

Guéguen, J. 1991. Pea and fababean proteins. p. 35-78. In B.J.F. Hudson (ed.) Development in food proteins. Vol. 7. Elsevier Applied Science, London and New York.

Higgins, T.J.V. 1984. Synthesis and regulation of major proteins in seeds. Annu. Rev. Plant Physiol. 35:191-221.

Jolliffe, I.T. 1986. Principal component anaiysis. Springer Verlag, Berlin.

Kooistra, E. 1962. On the differences between smooth and three types of wrinkled peas. Euphytica. 11:357-373.
Laemmli, U.K. 1970. Cleavage of structural proteins during the assemblage of the head of bacteriophage T4. Nature 227:680-685.

Larré, C., Y. Popineau, and W. Loisel. 1991. Fractionation of gliadins from common wheat by cation exchange FPLC. J. Cereal Sci. 14:231-241.

Matta, N.K., and J.A. Gatehouse. 1982. Inheritance and mapping of storage protein genes in Pisum sativum L. Heredity 48:383.392.

Matthews, P., and E. Arthur. 1985. Genetic and environmental components of variation in protein content of peas. p. 369-380. In P.D. Hebblethwaite et al. (ed.) The pea crop. A basis for improvement. Butterworths, London.

Mossé, J. 1990. Nitrogen to protein conversion factor for ten cereals and six legumes or oilseeds. A reappraisal of its definition and determination. Variation according to species and to seed protein content. J. Agric. Food Chem. 38:18-24.

Moore, S. 1963 . On the determination of cystine as cysteic acid. J. Biol. Chem. 238(1):235-237.

Müntz, K. 1989. Intracellular protein sorting and the formation of protein reserves in storage tissue cells of plant seeds. Biochem. Physiol. Pflanz. 185:315-335.

Perez, D., S. Chambers, J. Bacon, M. Morgan, N. Lambert, C. Hedley, and T. Wang. 1992. Quantitative analysis of pea seed proteins from existing and induced mutants. p. 173-174. In P. Plancquaert (ed.) Proc. of the First European Conference on Grain Legumes, Angers, France.1-3 June 1992. Assoc. Eur. Protéagineux, Paris.

Quillien, L., T. Gaborit, and J. Guéguen. 1995. Production and characterization of monoclonal antibodies against 11S storage protein from pea seeds. Phytochem. 39(5):969-976.

Randall, P.J., J.A. Thomson, and H.E. Schroeder. 1979. Cotyledonary storage proteins in Pisum sativum L. IV. Effects of sulfur, phosphorus, potassium and magnesium deficiencies. Aust. J. Plant Physiol. 6:11-24.

Rerie, W.G., M.I. Whitecross, and T.J.V. Higgins. 1991. Developmental and environmental regulation of pea legumin genes in transgenic tobacco. Mol. Gen. Genet. 225:148-157.

Scanlon, M.G., H.D. Sapirstein, and W. Bushuk. 1989. Computerized wheat varietal identification by high-performance liquid chromatography. Cereal Chem. 66(5):439-443.

Schroeder, H.E., 1982. Quantitative studies on the cotyledonary proteins in the genus Pisum. J. Sci. Food Agric. 33:623-633.

Thomson, J.A., and H.E. Schroeder. 1978. Cotyledonary storage proteins in Pisum sativum. II. Hereditary variation in components of the legumin and vicilin fractions. Aust. J. Plant Physiol. 5:281-294.

Turner, S.R., D.H.P. Barrat, and R. Casey. 1990. The effect of different alleles at the $r$ locus on the synthesis of seed storage proteins in Pisum sativum. Plant Mol. Biol. 14:793-803.

Wingad, C.E., M. Iqbal, M. Griffin, and F.J. Smith. 1986. Separation of hordein proteins from European barley by high-performance liquid chromatography: Its application to the identification of barley cultivars. Chromatographia 21(1):49-54. 